\title{
Synthetic Culture Media Evaluated for Detection of Coliform Bacteria in Milk, Cheese and Egg Melange
}

\author{
G. SZITA ${ }^{1}$, B. GYETVAI ${ }^{3}$, J. SZITA ${ }^{6}$, M. GYENES ${ }^{2}$, N. SOLYMOS ${ }^{4}$, L. SOOS ${ }^{4}$, A. HAJOS ${ }^{2}$, P. TOTH ${ }^{5}$, \\ S. BERNATH ${ }^{2}$ \\ ${ }^{1}$ Department of Food Hygiene, Faculty of Veterinary Science, Szent Istvan University, Budapest, Hungary \\ ${ }^{2}$ Institute for Veterinary Medicinal Products, Budapest, Hungary \\ ${ }^{3}$ Food and Feed Safety Directorate of Central Agricultural Office, Budapest, Hungary \\ ${ }^{4}$ Exxperimental Institute of Veterinary Science, Szent Istvan University, Budapest, Hungary \\ Large Animal Clinic, Faculty of Veterinary Science, Szent Istvan University, Hungary \\ ${ }^{6}$ National Institute of Traumatology and Emergency Medicine, Budapest, Hungary
}

Received November 28, 2006

Accepted December 19, 2007

\begin{abstract}
Szita G., B. Gyetvai, J. Szita, M. Gyenes, N. Solymos, L. Soos, A. Hajos, P. Toth, S. Bernath: Synthetic Culture Media Evaluated for Detection of Coliform Bacteria in Milk, Cheese and Egg Melange. Acta Vet. Brno 2008, 77: 143-147.

Simple synthetic culture media of liquid and solid form ( $\mathrm{X}$ broth and $\mathrm{X}$ agar) were tested for selective isolation of coliform bacteria. Selectivity is based on the ability of coliform bacteria to grow when the minimal medium contains simple inorganic substances as nitrogen and carbon supply. Selectivity of the media was tested by inoculation of pure cultures of different microbes belonging to the genera of Staphylococcus, Bacillus and Pseudomonas and the family Enterobacteriaceae and was found to be complete in this range. The comparative investigation of milk, camembert cheese and egg melange samples in the traditional and new media proved good applicability of X broth and X agar for an effective and selective detection of coliform bacteria. When testing pasteurized milk samples, $\mathrm{X}$ agar detected coliforms in significantly higher counts than violet red-bile-lactose agar.
\end{abstract}

Coliform, Escherichia coli, novel synthetic selective media, food

In food microbiology qualitative and quantitative determination of indicator flora is a commonly used procedure which allows rapid conclusions concerning possible contamination of a product (Ingham and Schmidt 2000). Previously we developed an acetamide-containing minimal medium for the selective isolation of Pseudomonas aeruginosa (Szita et al. 1998). It was also demonstrated that Escherichia coli could be grown in a minimal medium containing only an organic carbon source such as glucose, a nitrogen source such as $\left(\mathrm{NH}_{4}\right)_{2} \mathrm{SO}_{4}$, and minerals (Jay 1996). A new simple selective and differentiating synthetic medium (X broth), which is easy to prepare, was developed in a liquid form for the selective cultivation of coliform bacteria from foodstuffs. This synthetic medium contains ammonium salt as a nitrogen source, lactose as a carbon source, and buffer salts but is free of inhibitors. The selectivity of the $\mathrm{X}$ broth proved essentially better than that of the standard brilliant green-bile-lactose (BBL) broth. The results of nationwide tests of coliform bacteria determination demonstrated that there was no difference in reproducibility, but the comparability was significantly better when the $\mathrm{X}$ broth was used. Applicability of the synthetic medium (X broth) for a detection of coliform bacteria was also tested with good results by nationwide round tests on quick-frozen tomato paprika samples (Szita et al. 2003).

The purpose of this study was to test the applicability of the new synthetic medium (X broth) and its solid form (X agar) for the detection of coliform bacteria in milk, camembert cheese and egg melange samples.

Address for correspondence:

Dr. Bela Gyetvai

Food and Feed Safety Directorate of Central Agricultural Office

P.O. Box 1740, H-1465 Budapest, Hungary
Phone: $+36-14563013$

Fax: 36-1-216 1574

E-mail: gyetvaib@oai.hu

http://www.vfu.cz/acta-vet/actavet.htm 


\section{Materials and Methods}

Composition and preparation of media

The composition of violet red-bile-lactose (VRBL) agar (ISO/DIS 3811, International Organization for Standardization 1979$)$ is peptone $(7 \mathrm{~g} / 1)$, yeast extract $(3 \mathrm{~g} / \mathrm{l})$, lactose $(10 \mathrm{~g} / \mathrm{l})$, sodium taurocholate $(1.5 \mathrm{~g} / \mathrm{l})$, neutral red $(0.03 \mathrm{~g} / \mathrm{l})$, crystal violet $(0.002 \mathrm{~g} / \mathrm{l})$, agar $(16 \mathrm{~g} / \mathrm{l})$. Sterilisation at $121^{\circ} \mathrm{C}$ for $15 \mathrm{~min}$ was carried out in $10 \mathrm{ml}$ aliquots in Petri dishes.

The composition and preparation of brilliant green-bile-lactose (BBL) broth is as described in ISO/DIS 3811 (International Organization for Standardization 1979). Sterilisation at $121^{\circ} \mathrm{C}$ for $15 \mathrm{~min}$ was carried out in $10 \mathrm{ml}$ aliquots in test tubes.

The X broth (Hungarian Patent C12 N 1/20 (1987)) contained ammonium sulphate (1 g/l), lactose (4 g/l), potassium hydrogen phosphate $(3 \mathrm{~g} / \mathrm{l})$, magnesium sulphate $\times 7 \mathrm{H}_{2} \mathrm{O}(0.005 \mathrm{~g} / \mathrm{l})$. Sterilisation at $121^{\circ} \mathrm{C}$ for $15 \mathrm{~min}$ was carried out in $10 \mathrm{ml}$ aliquots in test tubes.

The composition of $X$ agar is: ammonium sulphate $(1 \mathrm{~g} / 1)$, lactose $(4 \mathrm{~g} / 1)$, potassium hydrogen phosphate (3 $\mathrm{g} / \mathrm{l})$, magnesium sulphate $\times 7 \mathrm{H}_{2} \mathrm{O}(0.005 \mathrm{~g} / \mathrm{l})$, agar $(18 \mathrm{~g} / \mathrm{l})$. Sterilisation at $121^{\circ} \mathrm{C}$ for $20 \mathrm{~min}$ was carried out in $10 \mathrm{ml}$ aliquots in Petri dishes.

\section{Bacterial strains}

The performance of the $\mathrm{X}$ broth was compared with that of the BBL broth by using the following test strains: Pseudomonas aeruginosa (ATCC 10145), Bacillus cereus (ATCC 14579), Staphylococcus aureus (ATCC 12600), Micrococcus luteus (ATCC 4698), Enterobacter aerogenes (ATCC 13048), Klebsiella pneumoniae (ATCC 13883), Citrobacter freundii (ATCC 8090), Salmonella enteritidis, (ATCC 13076), Proteus vulgaris (ATCC 13315), Yersinia enterocolitica (CIP Y.E. 160), Escherichia coli (ATCC 11775).

The strains were dispersed on nutrient agars and after incubation at $37^{\circ} \mathrm{C}$ for $16 \mathrm{~h}$ suspensions were prepared in saline from isolated colonies. The tenfold dilution series of bacterial suspensions from $10^{1}$ to $10^{7}$ from each dilution (in three parallels) were inoculated twice into the $\mathrm{X}$ broth and BBL broth according to the most probable number (MPN) method. The experiment was repeated with 20 E. coli and $24 \mathrm{~K}$. pneumoniae inoculations.

The bacterial suspensions of E. coli ATCC 25922 were inoculated on the X and VRBL agar media using the streak plate method. The experiment was repeated ten times.

\section{Food samples}

Ten TIHANY ${ }^{\circledR}$ and ten BAKONY ${ }^{\circledR}$ camembert cheeses were tested in the $\mathrm{X}$ broth and in the BBL broth, by weighing a $10 \mathrm{~g}$ cheese sample into $90 \mathrm{ml}$ sterile saline; then the mixture was homogenized in the Stomacher homogenizer, followed by preparing a dilution series and $1 \mathrm{ml}$ aliquots from each diluted sample were used for inoculation of test broth tubes.

The $\mathrm{X}$ broth and BBL broth were compared with each other based on determination of the coliform titres of 22 samples of egg melange.

Ten pasteurized milk samples were incubated at $30^{\circ} \mathrm{C}$ for $24 \mathrm{~h}$ in order to enrich the coliform bacteria. According to the experimental design, the $\mathrm{X}$ and the VRBL agar media were inoculated with tenfold dilution of milk samples.

\section{Experimental design}

To compare the liquid nutrient broth media, test tubes were used for $2 \times 3$ parallels in every dilution of bacterial suspensions of E. coli and K. pneumoniae. Each tube was inoculated with $1 \mathrm{ml}$ of tenfold diluted suspension of bacteria to be tested, using the most probable number (MPN) method. The broth cultures were incubated at $32{ }^{\circ} \mathrm{C}$ for $24 \mathrm{~h}$. Broths that exhibited turbidity and appreciable gas formation in the Durham tubes after incubation at $32{ }^{\circ} \mathrm{C}$ for $48 \mathrm{~h}$ were classified as coliform-positive. After logarithmic transformation of the MPN, the results were evaluated using the Generalized Linear Model. The results given were assessed in accordance with the Hoskins table (Hoskins 1933).

In the case of solid media (VRBL agar and $\mathrm{X}$ agar) $0.1 \mathrm{ml}$ of each sample dilution was spread onto the surface by the streak plate method. The results were calculated by colony counting. In order to determine the standard deviation of the method for every medium, two parallel inoculations were used for each sample. The agar media were incubated at $32{ }^{\circ} \mathrm{C}$ for $24 \mathrm{~h}$.

From each $\mathrm{X}$ and $\mathrm{BBL}$ broth showing gas formation, VRBL agars were plated, the dishes were incubated at $32{ }^{\circ} \mathrm{C}$ for 24 hours and the developing lactose fermenting colonies of $1-3 \mathrm{~mm}$ size were tested with API $20 \mathrm{E}$ kit for identification of coliforms.

Biometric evaluation of the results

The R environment (R Development Core Team 2003) was used as statistical application. To test the differences between the broths, analysis of variance was used. For evaluation of the first composition the Mixed Generalized Linear Model was used, with the type of broth as fixed effect and the parallel incubation strain as random effect applied.

The second array was a one-way analysis of variance (ANOVA) applying the General Linear Model function and using only the type of broth as fixed effect. 


\section{Results and Discussion}

Coliforms (including the inoculated 94 Escherichia coli strains) developed well in both media producing steady turbidity and simultaneous gas formation. The pattern of typical results (turbidity with gas) obtained with the $\mathrm{X}$ broth and BBL broth was identical. Among the Gram-positive and Gram-negative bacteria only the coliforms were able to grow and produce gas in the $\mathrm{X}$ broth, whereas most of the test bacteria produced turbidity in the BBL medium (Table 1).

Table 1. Comparison of the BBL broth and the synthetic (X) broth after inoculation with test bacteria. Coliform bacteria characteristically developed (with formation of gas) in both broths

\begin{tabular}{|l|c|c|c|}
\hline Test bacteria & Reference strain No. & BBL broth & X broth \\
\hline Pseudomonas aeruginosa & ATCC 10145 & + & - \\
\hline & & & \\
\hline Bacillus cereus & ATCC 14579 & + & - \\
\hline Staphylococcus aureus & ATCC 12600 & + & - \\
\hline Micrococcus luteus & ATCC 4698 & - & - \\
\hline & & & $\oplus$ \\
\hline Escherichia coli & ATCC 11775 & $\oplus$ & $\oplus$ \\
\hline Enterobacter aerogenes & ATCC 13048 & $\oplus$ & $\oplus$ \\
\hline Klebsiella pneumoniae & ATCC13883 & $\oplus$ & $\oplus$ \\
\hline Citrobacter freundii & ATCC 8090 & $\oplus$ & - \\
\hline & & & - \\
\hline Salmonella enteritidis & ATCC 13076 & + & - \\
\hline Proteus vulgaris & ATCC 13315 & + & - \\
\hline Yersinia enterocolitica & CIP Y.E. 160 & - & \\
\hline
\end{tabular}

$\oplus=$ turbidity, with gas formation

$+=$ turbidity, without gas formation

- = no turbidity
The logarithmic values for the coliform counts detected in BBL and $\mathrm{X}$ broths as well as in VRBL and $\mathrm{X}$ agars are given in Table 2 and Table 3. No significant $(p<0.05)$ difference in counts was found between the $\mathrm{X}$ broth and BBL broth using dilutions made from pure cultures of E. coli ATTC 11775 or K. pneumoniae ATCC 13883.

No significant differences were demonstrated between the two broths in coliform counts detected in TIHANY ${ }^{\circledR}$ $(p=0.3631)$ and BAKONY ${ }^{\circledR}$ $(p=0.0944)$ brands of camembert cheese.

Nor was there a significant difference between the two broth media in the MPN of coliforms detected in egg melange.

Every strain isolated from the $\mathrm{X}$ and BBL broth proved to be coliform bacteria. The isolates were E. coli, K. pneumoniae and Enterobacter aerogenes.

The use of the tested synthetic media failed to yield a higher number of coliform isolation rates as compared to the conventional BBL broth but its use had several advantages. Proteolytic bacteria can produce small amounts of gas from peptone components of broths (e.g. BBL) that contain these compounds of protein source. This does not occur when the synthetic medium (X broth) is used, because it does not contain peptone. Thus, by using the $\mathrm{X}$ broth diagnostic errors can be avoided. As the $\mathrm{X}$ broth is transparent, gas formation in it can be evaluated very easily and clearly. The synthetic medium does not contain inhibitors.

The bacterial counts obtained on the $\mathrm{X}$ agar media were significantly higher than on theVRBL agar, when pure culture of $E$. coli or pasteurized milk was examined.

Applicability of the new synthetic media for the detection of coliforms was tested using $E$. coli and $K$. pneumoniae strains that have great sanitary and food hygienic importance. E. coli is the most important species of the genus Escherichia as far as sanitation is concerned (Barrow and Feltham 1993; Jay 1996). K. pneumoniae is commonly found in the intestinal tract of humans and animals. It is frequently isolated in association with several pathological conditions in humans, e.g. from infections of the urinary and respiratory tracts. $K$. pneumoniae may be isolated from metritis in mares and also from bovine mastitis (Holt 
Table 2. Statistical analysis of coliform bacteria obtained in the liquid media X and the brilliant green-bile-lactose (BBL) broth evaluated by analysis of variance

\begin{tabular}{|c|c|c|c|c|}
\hline Sample & BBL $(\log \mathrm{MPN} / \mathrm{ml})$ & $\begin{array}{c}\mathrm{X} \text { broth } \\
(\log \mathrm{MPN} / \mathrm{ml})\end{array}$ & F value & $p$ value \\
\hline $\begin{array}{l}\text { 1. K. pneumoniae ATTC } \\
13883 \text { (MPN method) }\end{array}$ & $1.52 \pm 0.064$ & $1.43 \pm 0.062$ & 1.81948 & 0.1817 \\
\hline $\begin{array}{l}\text { 2. E. coli ATTC } 11775 \\
\text { (MPN method) }\end{array}$ & $1.39 \pm 0.088$ & $1.37 \pm 0.063$ & 0.40265 & 0.5282 \\
\hline $\begin{array}{l}\text { 3. Tihany }{ }^{\circledR} \text { camembert } \\
\text { cheese (MPN method) }\end{array}$ & $5.67 \pm 0.091$ & $5.53 \pm 0.138$ & 0.85376 & 0.3631 \\
\hline $\begin{array}{l}\text { 4. Bakony }{ }^{\circledR} \text { camembert } \\
\text { cheese (MPN method) }\end{array}$ & $3.77 \pm 0.088$ & $3.96 \pm 0.104$ & 2.99002 & 0.0944 \\
\hline $\begin{array}{l}\text { 5. Egg melange } \\
\text { (MPN method) }\end{array}$ & $3.95 \pm 0.213$ & $3.95 \pm 0.213$ & 0.0000 & 1.0000 \\
\hline
\end{tabular}

Table 3. Statistical analysis of coliform bacteria obtained on the $\mathrm{X}$ - and the violet red-bile-lactose (VRBL) agar evaluated by analysis of variance

\begin{tabular}{|l|c|c|c|c|}
\hline \multicolumn{1}{|c|}{ Sample } & $\begin{array}{c}\text { VRBL agar } \\
(\log \text { CFU/ml })\end{array}$ & $\begin{array}{c}\text { X agar } \\
(\log \text { CFU/ml })\end{array}$ & F value & $p$ value \\
\hline $\begin{array}{l}\text { 1. E. coli ATTC 25922 } \\
\text { (streak plate method) }\end{array}$ & $2.21 \pm 0.061$ & $3.34 \pm 0.027$ & 7.101 & $0.0125^{*}$ \\
\hline $\begin{array}{l}\text { 2. Pasteurized milk } \\
\text { (streak plate method) }\end{array}$ & $3.01 \pm 0.026$ & $3.33 \pm 0.011$ & 0.74434 & $<0.001^{*}$ \\
\hline
\end{tabular}

*denotes statistically significant differences $(p<0.05)$

1994). The results of tests carried out with pure cultures are especially important, as in this case complicated interactions cannot influence the results. As an additional advantage, the use of pure cultures makes it possible to avoid contamination of the media to be used with compounds such as lactose, fat and protein, which may exert an interfering effect during the examination. On the other hand, it is very important that food samples containing mixed microflora, as in the case of the camembert-type cheese, were contaminated by bacteria as well as moulds, which were also tested in this study. The selectivity of the synthetic media proved to be excellent in the tests, as exclusively E. coli, K. pneumoniae and E. aerogenes strains were isolated.

In summary, we have established that the $\mathrm{X}$ broth and the $\mathrm{X}$ agar can be applied effectively for the detection of coliforms from egg melange and camembert cheese. When used for examination of pasteurized milk samples, the X agar detected significantly higher coliform counts than the VRBL agar.

The advantages of the new synthetic media are their standard composition, reliability, low cost, easy preparation and absence of inhibitors. Further benefit is that the high selectivity of the new media makes it unnecessary to carry out several biochemical tests or other confirmatory examinations that are otherwise needed for the identification of certain bacteria.

\section{Hodnocení syntetických kultivačních médií pro detekci koliformních bakterií v mléku, sýru a vaječné směsi}

U jednoduchých syntetických kultivačních médií $\mathrm{v}$ kapalné i pevné podobě (X bujon a X agar) byla testována selektivní izolace koliformních bakterií. Selektivita je založena na schopnosti koliformních bakterií růst, obsahuje-li minimální médium jednoduché anorganické látky jako zdroj dusíku a uhlíku. Selektivita médií byla testována inokulací čistých kultur různých mikrobů rodu 
Staphylococcus, Bacillus a Pseudomonas a čeledi Enterobacteriaceae a bylo zjištěno, že je v tomto rozsahu kompletní. Srovnání vzorků mléka, sýru camembert a vaječné směsi v tradičních a nových médiích prokázal dobrou použitelnost médií X bujonu a X agaru pro efektivní a selektivní detekci koliformních bakterií. Při testování vzorků pasterizovaného mléka byl v X agaru nalezen významně vyšší počet koliformních bakterií než v agaru s krystalovou violetí, žlučí a laktózou.

\section{Acknowledgement}

The medium is patented in Hungary under C 12 N 1/20, 1987, (3).

\section{References}

BARROW GI, FELTHAM RKA (Eds.) 1993: Cowan and Steel's Manual for the Identification of Medical Bacteria. $3^{\text {rd }}$ ed. Cambridge University Press, Cambridge, $331 \mathrm{p}$.

HOLT JG 1994: Bergey's Manual of Determinative Bacteriology. $9^{\text {th }}$ ed. Vol. 1. Williams and Wilkins Co., Baltimore, pp. 67-69

HOSKINS JK 1933: The most probable numbers of Escherichia coli in water analysis. J Am Water Work Assoc 25: $867-877$

HUNAGRIAN PATENT C12 N 1/20, 1987: Procedure and synthetic medium for selective determination of coliform bacteria. Hungarian Patent Office (in Hungarian)

INGHAM SC, SCHMIDT DJ 2000: Alternative indicator bacteria analyses for evaluating the sanitary condition of beef carcasses. J Food Prot 63: 51-55

INTERNATIONAL ORGANISATION FOR STANDARDISATION 1979: Meat and meat products - detection and enumeration of presumptive coliform bacteria and presumptive Escherichia coli. International Standard ISO/DIS 3811

JAY JM 1996: Modern Food Microbiology. $5^{\text {th }}$ ed. Chapman and Hall, New York, 391 p.

R DEVELOPMENT CORE TEAM 2003: A language and environment for statistical computing. R Foundation for Statistical Computing, Vienna, Austria, ISBN 3-900051-00-3

SZITA G, BIRO G, TABAJDINE PV, FABIAN A 1994: Isolation of coliform bacteria using a synthetic liquidmedium. Magy Allatorv Lapja 49: 334-336

SZITA G, SCHMIDT E, BERNATH S, FALUDI G, FABIAN A, TABABAJDI V, KISS R 2003: A synthetic culture medium evaluated for detection of coliform bacteria in tomato paprika. Food Microbiol 20: 483-486

SZITA G, TABAJDI V, FABIAN A, BIRO G, REICHART O, KORMOCZY PS 1998: A novel, selective synthetic acetamide containing culture medium for isolating Pseudomonas aeruginosa from milk. Int J Food Microbiol 43: $123-127$ 
